\title{
WORKSHOP ONLINE: METODE SYSTEMATIC LITERATURE RIVIEW SEBAGAI ALTERNATIF KARYA ILMIAH AKHIR BAGI MAHASISWA DAN DOSEN DI MASA PANDEMI COVID-19
}

\author{
Edi Susanto, Rispianda, Arief Irfansyah, Hari Adianto, Ghifari Hamzah \\ Departemen Teknik Industri, Institut Teknologi Nasional Bandung \\ edsusanto@itenas.ac.id
}

\begin{abstract}
The aim of community service (PKM) is to provide alternative solutions for final year students and lecturers at PKM partners by introducing systematic literature review (SLR) research methods for final scientific works through online workshops amid the impact of the Covid-19 pandemic. With strict social distancing rules and a work from home (WFH) policy that limits/experiences difficulties in making student theses to conduct field research. Problems that exist with partners also have an impact on delays in final scientific works preparation. In contrast, the preparation of final scientific papers is an obligation as a requirement for graduation. Other things also have an economic impact due to the spread of layoffs for students' families/ guardians. Business activities are also not easy with the government's PSBB regulation through a circular, with restrictions on offline learning activities/ data collection in the field. Meanwhile, PKM partners also do not know the SLR method, so it is necessary to have an SLR method workshop as an alternative solution for conducting research using secondary data so that the research method policy can be an alternative solution. The evaluation of PKM activities is carried out with a pretest and a post-test before and after the workshop. Evaluation results of participants increased from the previous 49 to 82 or an increase of about 59\%. In general, this training was successful because it exceeded the indicator requirements, namely an average score of $>75$.
\end{abstract}

Keywords: Systematic Literature Review, Interactive Learning Method, Online Workshop

\begin{abstract}
Abstrak
Tujuan pengabdian masyarakat (PKM) adalah memberikan alternatif solusi bagi mahasiswa tingkat akhir dan dosen di mitra PKM, dengan memperkenalkan metode penelitian sistematis literature review (SLR) untuk karya ilmiah akhir melalui pelatihan online di tengah dampak pandemi Covid-19. . Dengan peraturan social distancing yang ketat dan kebijakan work from home (WFH) yang membatasi/ mengalami kesulitan dalam membuat skripsi mahasiswa tuntuk melakukan penelitian lapangan. Permasalahan yang ada pada mitra juga berdampak pada tersendatnya penyiapan skripsi, sedangkan penyiapan karya ilmiah akhir merupakan kewajiban sebagai syarat kelulusan, hal lain juga berdampak ekonomi akibat meluasnya PHK bagi keluarga/ wali mahasiswa, dan kegiatan bisnis juga tidak mudah dengan adanya peraturan PSBB dari pemerintah melalui surat edaran, dengan pembatasan kegiatan belajar tatap muka/ pendataan di lapangan. Sedangkan dosen dan mahasiswa mitra PKM juga belum mengetahui metode SLR ini, sehingga perlu adanya pelatihan metode SR sebagai alternatif solusi untuk melakukan penelitian dengan menggunakan data sekunder, sehingga kebijakan metode penelitian tersebut dapat menjadi alternatif solusi. Evaluasi kegiatan PKM ini dilakukan dengan pre-test di awal dan post test di akhir workshop. Hasil evaluasi peserta rata-rata meningkat dari sebelumnya 49 menjadi 82 atau meningkat sekitar 59\%. Artinya secara umum pelatihan ini berhasil karena melebihi persyaratan indikator yaitu skor rata-rata $>75$.
\end{abstract}

Kata kunci: Review Sistematis Literatur, Metode Pembelajaran Interaktif, Workshop Online

MARTABE : Jurnal Pengabdian Masyarakat | 246 


\section{PENDAHULUAN}

Dampak pandemi corona virus disease (Covid-19) hampir diasakan oleh hampir semua negara, termasuk Indonesia. Dampak ini menyentuh secara serius ke semua sektor, tak terkecuali sektor pendidikan dari semua jenjang. Kebijakan implementasi social distancing (jaga jarak sosial) dan work from home (bekerja/belajar dari rumah) dari pemerintah pada sektor pendidikan tertuang dalam Surat Edaran Kemdikbud No 36962/MPK.A/HK/2020, tentang Pembelajaran secara daring dan bekerja/belajar dari rumah, untuk mencegah penyebaran Covid-19. Surat Edaran ini, menuntut perguruan tinggi untuk secara cermat dan cepat untuk lebih kreatif dalam mensiasati dalam menghadapi masa pandemi ini. Beberapa aturan ini, memaksa dalam aktivitas pembelajaran di perguruan tinggi, untuk segera mungkin merubah metode pembelajaran, yaitu dari pembelajaran off line (tatap muka), beralih ke pembelajaran online (daring), baik perkuliahan, tugas sampai bimbingan karya ilmiah akhir. Sayangnya, kebijakan tersebut tidak memuat alternatif bagi dosen pembimbing skripsi dan mahasiswa tingkat akhir untuk jenjang perguruan tinggi untuk akan membuat karya ilmiah. Sehingga, para dosen pembimbing skripsi dan mahasiswa tingkat akhir merasa dilematis. Para mahasiswa ini, ingin lulus tepat waktu dengan alasan meringankan beban orangtua, sedangkan dosen juga punya key performance indikator (KPI), untuk menuntaskan pembimbingan skripsi mahasiswa bimbingannya. Namun yang terjadi justru sebaliknya. Mereka harus menunda kelulusan lantaran adanya kebijakan jaga jarak sosial yang menyulitkan mereka dalam proses pengerjaan karya ilmiah akhir, yaitu dalam melakukan penelitian lapangan.

Situasi ini tidak bisa disikapi dengan biasa saja, mengingat, pandemi ini juga berdampak pada sektor ekonomi semua lapisan masyarakat. Ancaman turunnya penghasilan sudah ada di depan mata, bahkan PHK mulai merebak terutama untuk orang tua mahasiswa. Sementara belum ada alternatif kebijakan dari Kemendikbud, yang membahas terkait biaya kuliah bagi mahasiswa akhir yang terpaksa menunda kelulusannya.

Beberapa permasalahan yang yang terjadi di lapangan, dosen kesulitan dalam memberikan solusi dan mahasiswa tingkat akhir PT di indonesia, juga di daerah mitra, mengalami kesulitan mengambil data primer di institusi/industri, akibatnya banyak mahasiswa mengalami stagnasi dalam pembuatan karya ilmiah akhir. Karya ilmiah pada jenjang sarjana sering disebut skripsi, yaitu karya ilmiah mahasiswa dalam menyelesaikan jenjang sarjana (Strata1). Skripsi didefinisikan sebagai karya ilmiah yang merupakan bukti unjuk kemampuan akademik mahasiswa dalam memecahkan permasalahan yang disusun berdasarkan kerangka teoretis dan metodologi tertentu (sesuai dengan bidang keilmuan atau program studi) dan dipertahankan di depan sidang penguji sebagai persyaratan untuk mencapai gelar sarjana. Penyusunan skripsi harus disertai dengan atau menghasilkan artikel yang siap diunggah pada jurnal nasional atau internasional (Rustono, dkk., 2018).

Yang terjadi di mitra PKM, STIE DR KHEZ Muttaqien sebgai salah satu perguruan tinggi (PT) yang menyelenggarakan program sarjana ekonomi dengan prodi manajemen dan akuntansi yang terkendala dengan situasi ini, karena kesulitan 
pengambilan data skripsi lapangannya. Sedangkan dosen pembimbing juga belum dapat memberikan solusi bagi mahasiswa bimbingannya. Permasalahn lain juga, bukan hanya sulitnya pengambilan data ke industri/institusi saja, tetapi hampir sebagian besar mahasiswa tingkat akhir di mitra PKM, juga mengalami permasalahan ekonomi, karena banyak orang tua yang terkena PHK terutama bagi orang tuanya sebagai pedagang juga sangat terasa, karena para pedagang mengalami penurunan penghasilan akibat aturan Pembatasan Sosial Berskala Besar (PSBB) dari Pemerintah beberapa waktu lalu, melalui Peraturan Pemerintah (PP) Nomor 21 Tahun 2020 tentang Dikarenakan wilayah mitra, yaitu purwakarta dan sekitarnya termasuk zona kuning dan sebagian merah. Kehati-hatian dalam penyelenggaraan kegiatan sosial yang memungkinkan adanya aktivitas keramaian pun ada pembatasan ketat. Kondisi sosial dan psikologis dari mahasiswa tingkat akhir juga mulai kurang bersemangat, karena sulitnya mendapatkan data primer dari industri/institusi.

Dari permasalahan yang ada diatas mengharuskan pihak PT mitra yang berinisiasi untuk bagaimana mencari solusi untuk menjawab permasalahan tersebut. Sehingga tim pengusul dari Institut Teknologi Nasional Bandung, memberikan dukungan pelatihan untuk mencari jalan keluar dalam masalah mitra ini, dan pihak mitra untuk dapat tetap melaksankan tugas akhir sebagai syarat kelulusan jenjang sarjana. Sehingga tugas akhir dilakukan bagaimana agar tidak harus mengambil data primer. Contoh model penelitian untuk tugas akhir yang tidak mengharuskan aktivitas pengambilan data ke lapangan/industri atau lebih dikenal dengan penelitian riset, memungkinkan untuk menggunakan alternatif dengan cara metode systematic literature review (SLR).

Penelitian SLR adalah metode tinjauan pustaka yang mengidentifikasi, menilai, dan menginterpretasi seluruh temuan-temuan pada suatu topik penelitian, untuk menjawab research question yang telah ditetapkan sebelumnya (Kitchenham dan Charters, 2007). Metode SLR yang dimaksud dilakukan secara sistematis adalah dengan mengikuti tahapan dan protokol yang memungkinkan proses tinjauan pustaka terhindar dari bias dan pemahaman yang bersifat subyektif dari penelitinya. SLR ini biasa dilakukan peneliti di bidang farmasi dan kedokteran, dan baru mulai dibawa ke bidang komputer mulai tahun 2007, sejak saat ini mulai beralih dalam perkembangannya dan telah digunakan di beberapa bidang software engineering (Hall, et al., 2018; Wahono, S.R., 2015), bidang software technolgy (Kitchenham et al., 2010; perlakuan dengan suatu outcome (Perry dan Hammond, 2002). bidang software technolgy (Kitchenham et al., 2010; Cruzes et al., 2011; Wen, rt al, 2012) dan bidang-bidang yang lain.

Dalam metode penelitian SLR ini menggunakan pendekatan metodologi yaitu kuantitatif dan kualitatif. Metodologi kuantitaif paada SLR digunakan untuk mensintesis hasilhasil penelitian dengan pendekatan kuantitatif, seperti randomized control trials (RCT), cohort study, casecontrol study, atau studi prevalensi. Pendekatan statistik juga dipakai dalam metode SLR, tujuannya untuk mensintesa hasil penelitian atau lebih dikenal dengan "meta-analisis". Sedangkan meta-analisis didefinisikan sebagai teknik melakukan agregasi data untuk mendapatkan hubungan sebab 
akibat antara faktor risiko atau perlakuan dengan suatu outcome (Perry dan Hammond, 2002). Pendekatan kualitatif dalam SLR diperuntukan untuk mensintesis/merangkum hasilhasil penelitian yang bersifat deskriptif kualitatif. Metode ini biasa disebut sebagai meta-sintesis (Perry \& Hammond, 2002). Sedangkan tahapan metode penelitian SR dengan pendekatan Kualitatif digunakan berdasarkan Francis dan Baldesari, (2006).
Pendekatan metode ini menggunakan data sekunder yang tidak memerlukan studi lapangan (data primer), maka penelitian dengan metode SLR, sangat memungkinkan menjadi alternatif solusi untuk dilskuksn di saat masa pandemi Covid19 ini. Dirasa perlu setiap perguruan tinggi untuk menerapkan metode penelitian dengan menggunakan data sekunder, sehingga dapat menjadi solusi dan mengurangi beban mahasiswa tingkat akhir ditengah pandemi ini.

Tabel 1. Permasalahan Mitra dan Solusi

\begin{tabular}{|c|c|c|c|c|c|}
\hline \multirow[t]{2}{*}{ No } & \multirow[t]{2}{*}{ Item Permasalahan } & \multirow[t]{2}{*}{$\begin{array}{l}\text { Faktor-faktor } \\
\text { Permaslahan }\end{array}$} & \multicolumn{2}{|c|}{$\begin{array}{c}\text { Permasalahan yang dihadapi } \\
\text { Mitra PKM }\end{array}$} & \multirow[t]{2}{*}{ Solusi } \\
\hline & & & Mahasiswa tingkat akhir & Dosen pembimbing & \\
\hline 1 & $\begin{array}{l}\text { Pengetahuan } \\
\text { mengenal SLR }\end{array}$ & $\begin{array}{l}\text { Belum mengetahui metode } \\
\text { SLR sebagai alternatif } \\
\text { pembuatan skripsi }\end{array}$ & $\begin{array}{l}\text { Mehasiswa belum paham } \\
\text { metode SLR sebagai } \\
\text { alternatf skripsi }\end{array}$ & $\begin{array}{l}\text { Dosen pembimbing skripsi } \\
\text { belum paham metode } \\
\text { sebagai alternatf skripsi }\end{array}$ & $\begin{array}{l}\text { Memberikan } \\
\text { pelatihan } \\
\text { metode SLR }\end{array}$ \\
\hline \multirow[t]{2}{*}{2} & $\begin{array}{l}\text { Terkendala } \\
\text { primer }\end{array}$ & $\begin{array}{l}\text {-Belum familiar } \\
\text { menggunaan data } \\
\text { sekunder dalam penelitian } \\
\text { untuk karya ilmiah (selain } \\
\text { data primer) }\end{array}$ & $\begin{array}{l}\text {-Selama ini Mahasiswa } \\
\text { hanya mengandalkan } \\
\text { penelitian lapangan }\end{array}$ & $\begin{array}{l}\text {-Selama ini Dosen hanya } \\
\text { mengandalkan pembimbingan } \\
\text { jenis penelitian lapangan }\end{array}$ & $\begin{array}{l}\text { sebagai } \\
\text { alternatif } \\
\text { pengganti } \\
\text { penelitian } \\
\text { lapangan di }\end{array}$ \\
\hline & & $\begin{array}{l}\text {-Beban ekonomi } \\
\text { mahasiswa yang berat } \\
\text { karena dampak covid-19 }\end{array}$ & $\begin{array}{l}\text {-Kebutuhan mahasiswa } \\
\text { untuk membuat dan } \\
\text { menyelesaikan } r \text { skripsi } \\
\text { skripsi denagan } \\
\text { relatif rendah }\end{array}$ & $\begin{array}{lc}\text {-Kebutuhan } & \text { Dosen } \\
\text { pembimbing } & \text { skripsi } \\
\text { mendapatkan solusi disaat } & \text { dan dalam proses } \\
\text { pandemi dembimbingan mahasiswanya } & \end{array}$ & $\begin{array}{l}\text { masa } \\
\text { pandemi }\end{array}$ \\
\hline 3 & $\begin{array}{l}\text { Metode } \\
\text { pelatihan/pembelajara } \\
\mathrm{n} \quad \text { virtual dengan } \\
\text { bantuan LMS google } \\
\text { scholar dan zoom }\end{array}$ & $\begin{array}{lr}\text { Pemanfaatan } & \\
\text { Laboratorium } & \text { Multimedia } \\
\text { dan TIK } & \text { belum } \\
\text { dimanfaatkan dosen dan } \\
\text { mahasiswa }\end{array}$ & $\begin{array}{lr}\text { Mahasiswa } & \text { belum } \\
\text { memahami } & \text { metode } \\
\text { pembelajaran } & \text { dengan } \\
\text { media } & \text { pembelajaran } \\
\text { interaktif dan daring } \\
\end{array}$ & $\begin{array}{l}\text { Dosen hanya mengandalkan } \\
\text { presentasi satu arah dan jarang } \\
\text { melibatkan interaktif dengan } \\
\text { metode pembelajaran dengan } \\
\text { media pembelajaran kolaborasi }\end{array}$ & $\begin{array}{l}\text { Metode } \\
\text { pembelajaran } \\
\text { untuk } \\
\text { meningkatkan } \\
\text { kompetensi }\end{array}$ \\
\hline 4 & $\begin{array}{l}\text { Program komprtensi } \\
\text { mahasiswa dan dosen } \\
\text { dalam penguasaan } \\
\text { metode SLR }\end{array}$ & $\begin{array}{l}\text { Mitra memiliki } \\
\text { kendala dalam } \\
\text { melakukan } \\
\text { pelatihan } \\
\text { peningkatan } \\
\text { kompetensi mahasiswa } \\
\text { dan dosen untuk metode } \\
\text { penelitian SLR secara } \\
\text { berkesinambunga }\end{array}$ & 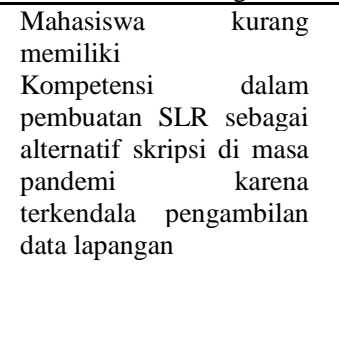 & $\begin{array}{l}\text { Dosen kurang memiliki } \\
\text { Kompetensi dalam pembuatan } \\
\text { SLR dan penyiapan } \\
\text { pembimbingan sebagai alternatif } \\
\text { skripsi dimasa pandemi } \\
\text { terkendala pengambilan data } \\
\text { lapangan }\end{array}$ & $\begin{array}{l}\text { SLR dengan } \\
\text { metode } \\
\text { interaktif } \\
\text { secara virtual } \\
\text { dengan } \\
\text { perangkat } \\
\text { google } \\
\text { clasroom dan } \\
\text { bantuan } \\
\text { aplikasi zoom } \\
\text { meeting }\end{array}$ \\
\hline
\end{tabular}

Hal ini terlihat di mitra, untuk para mahasiswanya hampir sebagian mengalami tunggakan pembayaran kuliah saat pandemi ini. Selain itu, masih sangat sedikit perguruan tinggi di indonesia, termasuk di wilayah mitra ini, yang mengenal model tugas akhir mahasiswa dengan SLR ini dan karena kebijakan pemerintah saat pandemi Covid-19 yang menerapkan kuliah online, sehingga dampaknya banyak perguruan tinggi/mahasiswa 
kebingungan dalam melakukan penelitian/riset lapangan, dengan terkendala protokol kesehatan dan larangan pengambilan data ke industri. Dengan demikian permasalahan mitra yang dihadapi saat ini adalah: 1) Belum mengetahui dan mengenal SLR terutama pada skripsi mahasiswa, 2) Kurangnya akses pengetahuan dan keterampilan metode penelitian skripsi mahasiswa, dengan mengenalkan metode SLR diharapkan akan menjadi solusi, akibat dampak kebijakan Kemendikbud yang mengharuskan kuliah online dan WFH akibat pandemi, sehingga dapat menjadi jawaban untuk meringankan dampak pandemi ini, sekaligus juga meringankan beban ekonomi bagi mahasiswa di wilayah mitra, untuk menerapkan model penelitian SLR ini. Adapun permasalahan mitra dan solusi yang ditawarkan dirangkum seperti tabel 1.

\section{METODE}

Metode pelaksanaan dalam pengenalan SLR sebagai alternatif solusi disepakati antara mitra dan tim pengusul PKM seperti berikut; Tahap pertama: Melakukan sosialisasi dan pengenalan pelatihan SLR dengan metode Collaborative learning, dimana pada metode ini tahapan yang dilakukan adalah; Partisipasi mitra pada tahap awal ini adalah sebagai host workshop, sedangkan untuk tim pengusul akan memberikan sosialisasi dan pengenalan dalam bentuk workshop online yang terdiri dari 3 modul dan 4 sesi, setiap modul materi diberikan evaluasi berbentuk pre test saat awal dan saat akhir sesi dilakukan post test. Selanjutnya, dilanjutkan tahap studi kasus pembuatan SLR dari penugasan selama 1 minggu untuk masing-masing peserta yang telah dikelompokan, dimana pada tahap ini, diikuti 36 peserta yang terdiri dari mahasiswa tingkat akhir dan dosen di PT mitra.

\section{Tahapan pelaksanaan}

Tahapan pelaksanaan PKM workshop online SLR ini, dengan pengembangan bahan ajar interactive learning dengan memamfatkan media online, sedangkan definisi dari Pembelajaran Interaktif adalah pendekatan pedagogis yang menggabungkan jejaring sosial dan komputasi perkotaan ke dalam desain dan penyampaian kursus (Wikipedia, 2020). Yang dilakukan tim PKM adalah sebagai berikut: 1) Membuat perangkat pelatihan; perangkat pelatihan dalam kegiatan pengabdian ini adalah perangkat pelatihan yang teridiri dari silabus pelatihan, modul pelatihan, slide presentasi, video pelatihan. Selain itu untuk menunjang pelaksanaan pelatihan secara online, tim pengusul dari Teknik Industri Itenas Bandung membuat kelas daring dengan menggunan aplikasi zoom meet dan google classroom, google classroom digunakan sebagai konten dari model pembelajaran e-learning (Suryanti, dkk., 2020), dalam PKM ini juga ditambahkan dengan whatshapp group untuk administrasi penugasan mengelola kelas workshop online. 2) Pelaksanaan pelatihan interaktif yang dilakukan secara interactive online learning yaitu dengan memanfaatkan learning management system (LMS) 
dengan google classroom dan didukung dengan media virtual kelas dengan zoom meeting. 3) Evaluasi; tahap ini, dilakukan dengan menggunakan pre test saat awal, untuk melihat sejauh mana peserta memahami materi workshop online SLR tersebut, sedangkan tahap penugasan kegiatan dilakukan selama seminggu (20 jam di kelas selama 2 hari, dan 10 jam dilakukan penugasan untuk membuat SR pada kelompok bidang masing-masing, selama rentang waktu 1 minggu dari tanggal 29 Agustus sd 5 September 2020, pada tahap setiap modul dilakukan post test untuk melihat tingkat pemahaman atas materi yang telah disampaikan

Evaluasi dilakukan untuk mengetahui sejauh mana keberhasilan pelaksanaan pembelajaran hasil program dengan menggunanan pendekatan metode interaltive virtual learning dengan media zoom meeting dan google classroom. evaluasi dilakukan pada kegaitan ini terdiri dari evaluasi pelaksanaan workshop untuk melihat ketercapaian program untuk para peserta. Evaluasi dilakukan dengan pre test dan post test melaui google form. Sementara evaluasi ketercapaian pelatihan merupakan evaluasi terhadap hasil pembelajaran interaktif melalui pelatihan online dengan yang dikembangkan oleh tim pengusul dan pihak mitra sebagai host.

\section{Tempat dan Waktu Pelaksanaan}

Workshop ini dilaksanakan secara online, di Laboratorium Komputer STIE Muttaqien, Jl. KK Singawinata No. 83, Nagri Kidul, Kecamatan Purwakrta, Kabupaten
Purwakarta, Jawa Barat 41111. Mitra yang terlibat pada kegiatan pengabdian ini adalah para dosen dan mahasiswa tingkat akhir STIE Dr KHEZ Muttaqien Purwakarta berada di tempat tinggal masing-masing, kegiatan ini dilaksankan 2 hari, yaitu sesi-1 tanggal 29 Agustus 2020, sedangkan sesi 2 pada tanggal 4 September 2020, sedangkan penugasan dilakukan antara rentang waktu tersebut.

\section{HASIL DAN PEMBAHASAN}

Hasil yang telah diperoleh dari program pengabdian kepada masyarakat yang telah dilaksanakan berdasarkan tahapan pelaksanaan kegiatan adalah sebagai berikut:

\section{Tahap Persiapan Pelatihan SLR}

Hasil yang diperoleh pada tahap pengenalan SLR adalah materi pelatihan bagi mahasiswa tingkat akhir dan dosen dengan 3 modul yang dibagi menjadi 4 sesi waktu pelatihan, Video tutorial untuk persiapan yaitu; cara akses jurnal seperti; WoS, Scopus, Proquest, Publons, Garuda, Sinta, cara membuat akun Google Scholar, Researchgate, Academia, cara membuat akun dan mengunakan manajemen referensi, seperti Mendeley/Zotero, cara membuat akun dan menggunakan google translate/bing translate, cara memparafrase kalimat dengan aplikasi Tools 4Noobs, cara menggunakan aplikasi Grammary untuk memperbaiki tata bahasa, cara menggunakan aplikasi pagiarism dengan Turnitin/Ithenticate dan template untuk format SLR. Perangkat/tools tersebut digunakan 
untuk mempermudah membuat tahapan SLR dengan pembelajaran virtual learning melalui pembelajaran interaktif online dengan menggunakan perangkat LMS seperti google clasroom dan zoom metting. Sedangkan form pendaftaran awal pelatihan menggunakan googlen form.

\section{Tahap Pelaksanaan Pelatihan}

Pelaksanaan pelatihan dilakukan melaui tahapan-tahapan berikut; pelatihan dengan metode daring ini dilakukan dengan 2 hari kelas online dan penugasan setara 1 hari dalam rentang 1 minggu tersebut,, minggu ke1 dilakukan tanggal 29 september dan minggu ke-2 tanggal 4 september 2020. Dengan membagi kedalam 4 sesi dan 3 modul.

\section{Workshop Online}

Pada kegiatan worksop online ini dilaksanakan dari tempat tinggal peserta dengan aplikasi zoom meeting dengan jumlah peserta 36 orang yang terdiri dari dosen 9 orang dan mahasiswa 27 orang, komposisi presentase dari peserta seperti pada gambar 1. Pada pertemuan hari pertama merupakan kegiatan pembukaan dan sosialisasi metode SLR kegiatan pelatihan pada para peserta workshop. Pada kegiatan ini, para peserta diberikan penjelasan mengenai teknis pelaksanaannya dengan menggunakan metode penyampaian materi secara online. Pada kegiatan pembukaan dan sosialisasi ini dilakukan simbolisasi pembukaan yang dilakukan oleh ketua LPPM STIE Dr. KHEZ Muttaqien bersama ketua tim pegusul PKM Institut
Teknologi Nasional Bandung, seperti pada gambar 2 .

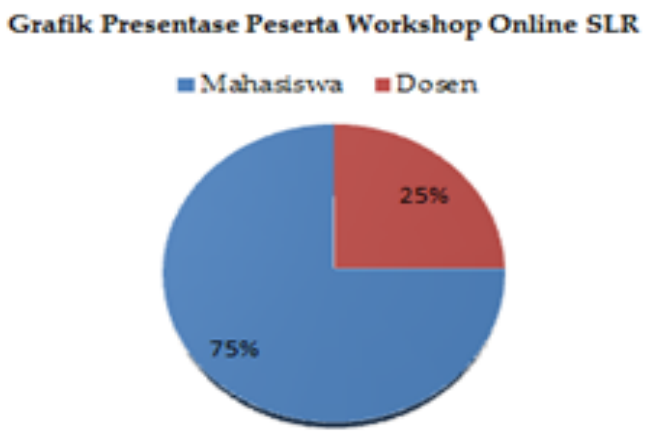

Gambar 1. Komposisi Peserta Workshop Online SLR

Pelatihan hari kedua pada tanggal 4 Septemper 2020 dengan tahapan studi kasus pembuatan paper SLR secara sederhana, seperti pada gambar 3 .

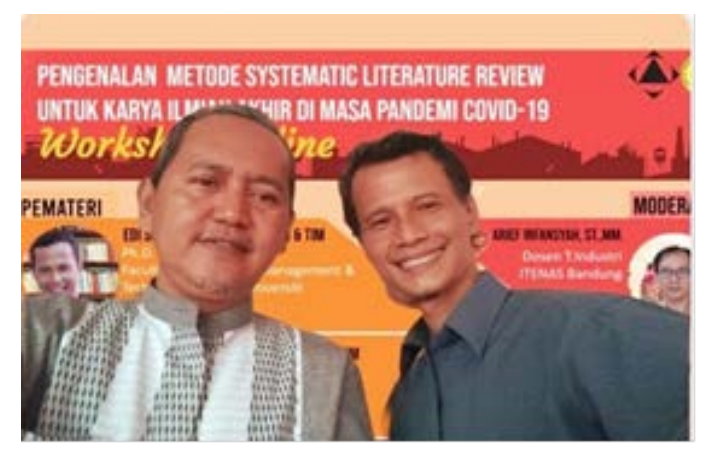

Gambar 2. Pembukaan Kegiatan PKM

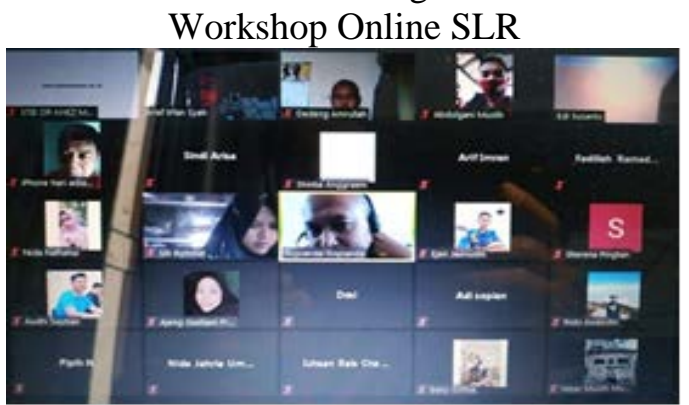

Gambar 3. Penyampaian materi online via zoom meeting

\section{Tahapan diskusi studi kasus pembuatan SLR}

Penyampaian materi ini yang dibahas tentang hasi SLR dari para mahasiswa dan dosen yang telah dibuat 
Edi Susanto, dkk. Workshop Online: Metode Systematic Literature Riview ...

dengan pendekatan interactive learning dengan online melalui zoom meeting. Kemudian dari masing-masing peserta yang terdiri dari 5 kelompok masingmasing diberi kesempatan untuk mengajukan pertanyaan hasil pembuatan SLR yang telah dibuat dari penugasan selama 1 minggu melalui google classroom, sedangkan kelompok lain wajib memberi pernyataan dan masukan, ketika ada yang tidak sesuai dengan pemahaman mereka. Para anggota kelompok menjawab pertanyaan yang diajukan oleh kelompok lain dan narasumber memfasilitasi dan memberikan feedback dan arahan sesuai dengan materi studi kasus tersebut.

\section{Tahap Evaluasi}

Tahap evaluasi pelaksanaan pelatihan dilakukan tim pengusul PKM dilakukan saat sebelum setiap sesi mulai dengan pre test dan setelah pelaksanaan kegiatan pelatihan selesai dilakukan post test melalui google form. dari evaluasi pelaksanaan pelatihan ketiga modul materi tersebut. Selanjutnya hasil tersebut diolah dan ditentukan nilai minimal indikator keberhasilan apabila mendapatkan nilai sebesar $>75$ (skala 100) (Heru, H., \& Yuliani, R. (2020).

Tabel 2. Hasil Evaluasi Peserta Workshop SLR Online

\begin{tabular}{|c|c|c|c|c|c|c|c|c|c|}
\hline \multirow{2}{*}{$\begin{array}{c}\text { Kode } \\
\text { Peserta }\end{array}$} & \multicolumn{3}{|c|}{ Hasil pre test } & \multirow{2}{*}{$\begin{array}{l}\text { Rata- } \\
\text { rata }\end{array}$} & \multicolumn{3}{|c|}{ Hasil post test } & \multirow{2}{*}{$\begin{array}{c}\text { Rata- } \\
\text { rata }\end{array}$} & \multirow{2}{*}{$\begin{array}{l}\text { pening- } \\
\text { katan }\end{array}$} \\
\hline & Modul 1 & Modul 2 & Modul 3 & & Modul 1 & Modul 2 & Modul 3 & & \\
\hline M-1 & 30 & 40 & 50 & 40 & 70 & 80 & 70 & 73 & $83 \%$ \\
\hline M-2 & 45 & 45 & 45 & 45 & 65 & 70 & 90 & 75 & $67 \%$ \\
\hline M-3 & 50 & 20 & 30 & 33 & 70 & 80 & 80 & 77 & $130 \%$ \\
\hline M-4 & 10 & 30 & 30 & 23 & 70 & 75 & 80 & 75 & $221 \%$ \\
\hline M-5 & 45 & 45 & 45 & 45 & 60 & 80 & 90 & 77 & $70 \%$ \\
\hline M-6 & 25 & 60 & 60 & 48 & 70 & 75 & 70 & 72 & $48 \%$ \\
\hline M-7 & 50 & 65 & 30 & 48 & 80 & 85 & 95 & 87 & $79 \%$ \\
\hline M-8 & 25 & 60 & 50 & 45 & 80 & 70 & 90 & 80 & $78 \%$ \\
\hline M-9 & 45 & 50 & 30 & 42 & 70 & 85 & 50 & 68 & $64 \%$ \\
\hline M-10 & 30 & 40 & 60 & 43 & 70 & 75 & 86 & 77 & $78 \%$ \\
\hline M-11 & 35 & 40 & 55 & 43 & 70 & 75 & 80 & 75 & $73 \%$ \\
\hline M-12 & 30 & 60 & 50 & 47 & 80 & 85 & 100 & 88 & $89 \%$ \\
\hline M-13 & 30 & 50 & 50 & 43 & 75 & 80 & 70 & 75 & $73 \%$ \\
\hline M-14 & 30 & 55 & 45 & 43 & 70 & 70 & 90 & 77 & $77 \%$ \\
\hline M-15 & 20 & 50 & 65 & 45 & 70 & 80 & 85 & 78 & $74 \%$ \\
\hline M-16 & 25 & 30 & 55 & 37 & 70 & 90 & 75 & 78 & $114 \%$ \\
\hline M-17 & 45 & 40 & 50 & 45 & 80 & 90 & 80 & 83 & $85 \%$ \\
\hline M-18 & 30 & 40 & 30 & 33 & 75 & 85 & 70 & 77 & $130 \%$ \\
\hline M-19 & 30 & 40 & 55 & 42 & 70 & 80 & 75 & 75 & $80 \%$ \\
\hline M-20 & 50 & 60 & 60 & 57 & 70 & 85 & 90 & 82 & $44 \%$ \\
\hline M-21 & 30 & 40 & 50 & 40 & 70 & 80 & 80 & 77 & $92 \%$ \\
\hline M-22 & 20 & 50 & 50 & 40 & 70 & 80 & 75 & 75 & $88 \%$ \\
\hline M-23 & 55 & 30 & 55 & 47 & 80 & 80 & 90 & 83 & $79 \%$ \\
\hline M-24 & 55 & 30 & 55 & 47 & 70 & 90 & 80 & 80 & $71 \%$ \\
\hline M-25 & 25 & 50 & 45 & 40 & 65 & 75 & 70 & 70 & $75 \%$ \\
\hline
\end{tabular}


MARTABE : Jurnal Pengabdian Masyarakat Vol 4 No 1 Tahun 2021 Hal 246-257

\begin{tabular}{|c|c|c|c|c|c|c|c|c|c|}
\hline M-26 & 25 & 30 & 50 & 35 & 75 & 90 & 80 & 82 & $133 \%$ \\
\hline M-27 & 25 & 20 & 40 & 28 & 75 & 80 & 80 & 78 & $176 \%$ \\
\hline \multicolumn{4}{|c|}{$\begin{array}{c}\text { Rata-Rata Pre Test } \\
\text { Mahasiswa }\end{array}$} & 45 & \multicolumn{3}{|c|}{ Rata-Rata Post Test Mahasiswa } & 78 & $54 \%$ \\
\hline D-1 & 56 & 60 & 50 & 55 & 90 & 70 & 100 & 87 & $57 \%$ \\
\hline D-2 & 60 & 65 & 55 & 60 & 90 & 80 & 100 & 90 & $50 \%$ \\
\hline D-3 & 50 & 60 & 55 & 55 & 75 & 85 & 90 & 83 & $52 \%$ \\
\hline D-4 & 50 & 50 & 45 & 48 & 80 & 90 & 85 & 85 & $76 \%$ \\
\hline D-5 & 50 & 60 & 60 & 57 & 80 & 90 & 80 & 83 & $47 \%$ \\
\hline D-6 & 60 & 70 & 60 & 63 & 90 & 100 & 100 & 97 & $53 \%$ \\
\hline D-7 & 50 & 45 & 50 & 48 & 80 & 90 & 80 & 83 & $72 \%$ \\
\hline D-8 & 50 & 60 & 50 & 53 & 80 & 80 & 100 & 87 & $63 \%$ \\
\hline D-9 & 55 & 70 & 60 & 62 & 80 & 80 & 85 & 82 & $32 \%$ \\
\hline \multicolumn{4}{|c|}{ Rata-Rata Pre Test Dosen } & 56 & \multicolumn{3}{|c|}{ Rata-Rata Post Test Dosen } & 86 & $65 \%$ \\
\hline \multicolumn{4}{|c|}{$\begin{array}{l}\text { Rata-Rata Pre Test } \\
\text { Mahasiswa \& Dosen }\end{array}$} & 49 & \multicolumn{3}{|c|}{$\begin{array}{c}\text { Rata-Rata Post Test Mahasiswa \& } \\
\text { Dosen }\end{array}$} & 82 & $59 \%$ \\
\hline
\end{tabular}

Data hasil evaluasi pre test dan post test pada tabel 2. Dari hasil data tabel 2, Ditampilkan diagram batang seperti pada gambar 4, dapat kita lihat peningkatan masing-masing peserta setiap hasil evaluasi dari pre test dan post test untuk kelompok mahasiswa terjadi peningkatan rata-rata $54 \%$ darinilai 45 meningkat menjadi 78\%, sedangkan unruk kelompok dosen peningkatan sebesar $65 \%$ dari nilai ratarata 56 menjadi 86. Sehingga rata-rata gabungan keduanya adalah 59\% atau meningkat dari rata-rata nilai saat pre test memperoleh nilai 49 menjadi 82 setelah post test.

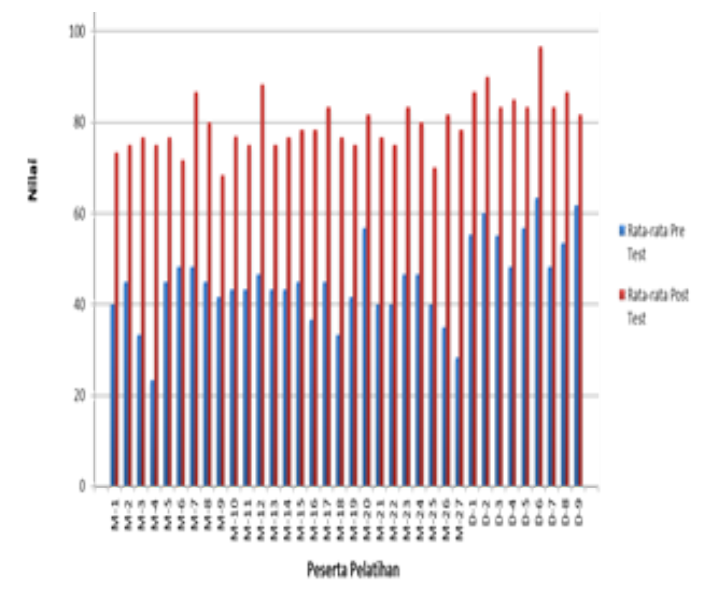

Gambar 4. Diagram Keberhasilan peserta Workshop Online SLR

\section{SIMPULAN}

Dari hasil kegiatan PKM dan hasil pembahasan dapat disimpulkan bahwa;

- Permasalahan prioritas pada kegiatan PKM ini adalah untuk meningkatkan kemampuan menulis karya ilmiah metode SLR sebagai alternatif penelitian skripsi di saat pandemi dengan metode teoritical research, dengan pemanfaatan berbagai macam perangkat/tools pendukung yang telah diajarkan dalam workshop online SLR.

- Hasil evaluasi pemahaman peserta pelatihan meningkat dari 49 menjadi 82 atau naik rata-rata 59\%.. Secara umum hasil pelatihan berhasil karena selain hasil rata-rata post test para peserta memperoleh nilai > 75, artinya hasil evaluasi yang ada peningkatan pemahan dan para peserta sudah bisa membuat SLR sederhana dengan tahapan yang sesuai. Namun diras perlu untuk mengembangkan 
Edi Susanto, dkk. Workshop Online: Metode Systematic Literature Riview ...

metode pembelajaran studi kasus bukan hanya interaktif saja tapi kedalam metode workshop online dengan metode collaborative learning, agar keterlibatan semua peserta lebih dapat ditingkatkan agar pemahaman para peserta lebih merata dan optimal..

- Metode penelitian SLR ini cukup penting dan dapat menjadi solusi, mengingat situasi pandemic tak kunjung usai, sehingga perlunya tahap implementasi yang real untuk segera dibuat pedoman untuk pembuatan skripsi mahasiswa dengan metode penelitian SLR ini sebagai solusi alternatif yang mendesak untuk diimplementasikan

\section{UCAPAN TERIMA KASIH}

Terimakasih kepada Prodi Teknik Industri dan LP2M Institut Teknologi Nasional Bandung yang sudah mendukung dan membiayai PKM Pelatihan SLR ini untuk mahasiswa tingkat akhir dan dosen STIE Dr. KHEZ Muttaqien tahun anggaran 2020.

\section{DAFTAR PUSTAKA}

Cruzes et al.,, (2011). Research synthesis in software engineering: A tertiary study, Information and Software Technology. 53.

Francis C. \& Baldesari (2006). Systematic Reviews of Qualitative Literature. Oxford: UK Cochrane Centre.

Hall, T., Beecham, S., Bowes, D., Gray, D., \& Counsell, S. (2012). A
Systematic Literature Review on Fault Prediction Performance in Software Engineering. IEEE Transactions on Software Engineering, 38(6), 12761304.

Heru, H., \& Yuliani, R. (2020). Pelatihan Pengembangan Bahan Ajar Multimedia Pembelajaran Interaktif Berbasis Pendekatan Saintifik Menggunakan Metode Blended Learning bagi Guru SMP/MTs Muhammadiyah Palembang. Jurnal Pengabdian Pada Masyarakat, 5(1), 35-44.

Jianfeng Wen, Shixian Li, Zhiyong Lin, Yong Hu, Changqin Huang, (2012). Systematic literature review of machine learning based software development effort estimation models. Information and Software Technology. 54 (4159).

Kitchenham, B., \& Charters, S. (2007). Guidelines for performing Systematic Literature Reviews in Software Engineering. EBSE. Technical Report Version 2.3, EBSE.

Kitchenham et al., (2010). Systematic literature reviews in software engineering A tertiary study. Information and Software Technology. 52.

Perry, A. \& Hammond, N. (2002). Systematic Review: The Experience of a $\mathrm{PhD}$ Student. Psychology Learning and Teaching. 2(1), 32-35. 
Rustono, Januarius, M., Hartono, R., Wagiran., Syaifudin, A., Surahmat, S. Rustono, Januarius, M., Hartono, R., Wagiran., Syaifudin, A., Surahmat, S. (2018) Panduan Penulisan Karya Ilmiah Universitas Negeri Semarang. Penerbit UNNES PRESS Cetakan ke-1 (xii + 108 hal. $25,7 \mathrm{~cm}$ )

....., Peraturan Pemerintah (PP) Nomor 21 Tahun 2020 tentang Pembatasan Sosial Berskala Besar (PSBB).

......,Surat Edaran Kemdikbud No 36962/MPK.A/HK/2020, tentang Pembelajaran Secara Daring dan Bekerja/Belajar dari Rumh Untuk Mencegah Penyebaran Corona Virus Disease (Covid-19).

Subekti, A. S., \& Kurniawati, L. A. (2020). Pelatihan Mendesain Pembelajaran Daring Menarik Selama Pandemi Covid-19 dengan Teknologi Pembelajaran Sederhana.
Dinamisia: Jurnal Pengabdian Kepada Masyarakat, 4(4), 588595.

Suryanti, S., Edy, S., \& Uchtiawati, S. (2020). Pelatihan Pengembangan Konten ELearning Menggunakan Google Classroom Sebagai Inovasi Pembelajaran Guru Matematika SMP. MARTABE: Jurnal Pengabdian Masyarakat. 3 (2), 281-287.

Wahono, R.S., (2015). A Systematic Literature Review of Software Defect Prediction: Research Trends, Datasets, Methods and Frameworks. Journal of Software Engineering,. 1 (1) Wikipedia, (2020). https://en.wikipedia.org/wiki/In teractive_Learning. Diakses 16 Desember 2020. 